\title{
OPVATTINGEN VAN ZUID-AMERIKAANSCHE INDIANEN NOPENS ZIEKTEN EN GENEESWIJZEN
}

DooR

\author{
JHR. L. C. VAN PANHUYS
}

Ik wensch de gedachten van de lezers van de West-Indische Gids te bepalen bij het in het hart van Zuid-Amerika gelegen Gran Chaco-gebied en zijne bewoners en dan ook eene vergelijking te maken met hetgeen over opvattingen van Surinaamsche Indianen betreffende genezing van ziekten door een zeer betrouwbaar waarnemer, uit zijn ervaring is medegedeeld. "Chaco" is de Spaansche vorm van het Quicha-woord chacu, voor: jacht, betrekking hebbende op de groote jaarlijksche jachttochten van de Inka's, waarbij duizenden Indianen als drijvers werden gebezigd. De benaming werd later toegepast op de Indianen die zich aan dergelijke jacht wijdden, en aan de landstreken waar ze plaats had. De Inka's kenden echter slechts de met bosch begroeide oosthellingen van de Cordilleras en de aangrenzende vlakten, dus slechts een klein deel van het enorme gebied, dat thans Chaco heet. De binnenlanden, speciaal die ten oosten van de Pilcomayo-rivier, die door onafhankelijke Indianen werden bewoond, waren aan de Inka's onbekend en werden eerst in den jongsten tijd onderzocht.

Het klimaat van het tusschen 20 en 30 graden zuiderbreedte gelegen gebied is subtropisch maar aan groote veranderingen onderhevig. In het westen is de jaarlijksche regenval overvloedig en de plantengroei zeer weelderig; naar het oosten wordt de regenval geleidelijk minder en treft men grasvlakten en woestijngebied aan. Nergens zal men in de pampa's steenen aantreffen; de Chaco-Indianen moeten zich in de plaats daarvan met ijzerhout voor wapenen en gereedschap behelpen. Van de vezels van een Bromelia doorngewas vervaardigen zij netten, zakken en hemden; de algaroba (Prosopis alba) geeft een zeer suikerrijke vrucht, die twee of drie maanden van het jaar duizenden Indianen voedt. Van October tot Maart (het zomerseizoen) valt 
de meeste regen en kunnen de inboorlingen pompoenen, watermeloen, maniok en maïs verbouwen, de temperatuur rijst dan vaak tot $110^{\circ} \mathrm{F}$. in de schaduw. Na Maart begint een droogteseizoen met koude zuidewinden, en dan kan het in den vroegen morgen soms vriezen. Er houden zich groote kudden (Amerikaansche) struisvogels op, en nabij het woudgebied groote troepen peccari's (wilde zwijnen). De jaguar en de miereneter zijn er de gevaarlijkste dieren. De Pilcomayo-Indianen leven hoofdzakelijk van de overvloedige visch. In den zomer zijn de insecten zeer taltijk en de muskieten zeer lastig; toch is het klimaat gezond. Malariakoortsen komen er niet voor, behoudens in zeer beperkt aantal en dan alleen door vreemden (blanken) ingevoerde gevallen, maar de inboorlingen lijden het meest aan rheumatiek en catarrh. Ontdekkingsreizigers zouden er, tenzij zij den rivierloop blijven volgen, zonder Indiaansche gidsen binnen enkele dagen van dorst omkomen. Slechts de Indiaan weet de schaarsche kleine waterpoelen, met stinkend bruin of groen water, te vinden. De vijandige houding van de inboorlingen droeg er toe bij, dat het binnenste gebied nog voor een groote uitgestrektheid onbekend is. Dr. J. Crevaux werd er door de Indianen vermoord.

De hoogleeraar R. Karsten, Ph. D., professor in de wijsbegeerte aan de universiteit te Helsingfors, dien ik in 1930 op het Amerikanisten-Congres te Hamburg, en in den zomer van 1934 op het Eerste Internationale Congres voor anthropologische en ethnologische wetenschappen te Londen ontmoette, heeft in een in 1932 te Helsingfors uitgekomen boek o.m. in het bijzonder de gedachtenwereld, de denkbeelden, van door hem in de Chaco bezochte Indianen beschreven, en hij zegt daarin, dat het onderzoek naar die denkbeelden hem veel inspanning heeft gekost en slechts door een langdurig onderzoek mogelijk was. Uiteraard hadden gewone reizigers en natuuronderzoekers, maar ook volkenkundigen, aan dit onderwerp tot nog toe weinig aandacht geschonken.

Zooals eigenlijk bij alle Zuid-Amerikaansche (en dus ook bij de Surinaamsche) Indianen komt ook bij de Chaco-Indianen, bij wijze van compensatie voor hun gebrek aan begrip van natuur(kundige) wetten, het geloof aan den invloed van goede en kwade geesten. Ziekte en dood bijvoorbeeld, die anders voor hen geheel onverklaarbaar zouden zijn, schrijven zij toe aan bijzonder kwaadaardige demonen, die slechts door tooverdansen en bezweringen kunnen worden verdreven. De demonen komen - de lezer zal, hoop ik, wel willen opmerken, dat ik thans de Indiaan- 
sche denkwijze en niet eigen kennis of overtuiging weergeef slechts bij nacht uit bosch en struikgewas om de hutten van de Choroti te bezoeken. Het zijn de zielen van afgestorvenen, naar het schijnt, want de Choroti-naam voor een demon, mòhsek is tevens het woord voor den geest, die in het graf verblijft waar het stoffelijk overschot ter aarde is besteld. In den kouden zuidewind, die rheumatiek en verkoudheid meebrengt, huizen kwade geesten; in den warmen noordewind, goede .Booze geesten kiezen een zoo zeldzaam voorwerp als een steentje tot woonplaats, zoodat de medicijnman die een patient geneest, de ziekte in den vorm van een steentje uit zijn lichaam kan halen. Ziekte ontstaat altijd door bovennatuurlijke werking; de Indianen zijn er zich van bewust, dat epidemische ziekten als kinderpokken, malariakoorts, dysenterie, enz. door de blanken worden ingevoerd en zij nemen aan, dat hun eigen geneeskundigen tegen die ziekten machteloos zijn.

De kwade geesten, die 's nachts in grooten getale komen aanvliegen, houden de Indianen op een afstand door dansen, door op de trom te slaan, en door reeds aangevallen patienten door bezweringen te genezen. De medicijnmannen kunnen ze ontwaren, omdat ze helderziende zijn, en ze kunnen met de geesten in verbinding treden. De medicijnman heeft zijn (en de meeste oude lieden hebben hun eigen) beschermgeest, die hem (hen) bijstaat.

In het droge jaargetijde lijden oud en jong menigmaal aan rheumatische pijnen. Zooals wij weten, komen die plotseling op en nu doet zich de zeer merkwaardige gedachtencoïncidentie voor, dat beschaafden voor zulke plotselinge ongesteldheden namen gebruiken als: fairy-dart en Hexenschuss. Wij schijnen dus vroeger een soortgelijk (primitief) begrip te hebben gehuldigd. Voor den Indiaan wordt de pijn veroorzaakt, doordat de booze geest een pijl afschiet, die de medicijnman of zijn beschermgeest in den vorm van een cactus-doorn, een steentje, een stukje been of een insect uit het lichaam van den patient haalt. Voor den primitieven mensch is deze „pijl” half wezenlijk, half onwezenlijk, maar toch vaste werkelijkheid, omdat de vreeselijke uitwerking niet kan worden geloochend. De door koude veelvuldig veroorzaakte keel- en borstaandoeningen zijn, naar Indiaansche zienswijze, buiten kijf te wijten aan het indringen van een boozen geest in het pijnlijke lichaamsdeel. De medicijnman moet dien demon uitdrijven, omdat anders de patient zou bezwijken. Daartoe vangt de medicijnman aan met tegen de pijnlijke plek te spuwen en te blazen, ten einde die plek (zooals hij het zich voor- 
stelt) van kwaad te ontdoen, te „desinfecteeren”, en het verwijderen van de (zoogenaamde) pijl mogelijk te maken. Speeksel wordt (als zielestof?) heilig gedacht; dat van den medicijnman in het bijzonder. Aan den demon zingt de medicijnman bepaalde woorden (formules) toe, en zijn stem, zijn adem, en zelfs het rhythme van het gezang, versterken de bezwering. Tot den beschermgeest wordt bij de Matako een soort van gebed gericht. Ieder mensch wordt door den Indiaan geacht een zekeren weerstand tegen ziekte, tegen den ziekte-demon, een zekere immuniteit te bezitten. Een dans van het geheele dorp is echter noodig bij hardnekkige ziekteaanvallen en bij epidemieën. De dans draagt ook een prophylactisch karakter. Er moet, zoo mogelijk door den patient zelf, goed bij gezweet worden, omdat zweeten (volgens de Indiaansche denkwijze) helpt bij de zuivering van kwade invloeden. Het aangezicht van de dansers en danseressen wordt voorzien van bepaalde ornamenten van orleaan (urucu, Bixa orellana), welke ornamenten tooverkracht hebben om geesten af te houden en te verdrijven. De ratel vervult mede een zoodanige taak.

Ziet men in het uur voor de schemering en tijdens het invallen van het duister, zoo verhaalt ons Dr. K., een bejaarden Indiaan onder het mompelen van eenige onverstaanbare woorden met een ratel in de hand zitten, die hij af en toe schudt, dan weten wij waarmede hij zich bezig houdt: in het belang van zichzelf, van het gezin, van de dorpsgenooten, tracht hij de tegen den avond uit het struikgewas aanvliegende booze geesten een beletsel in den weg te leggen, zoodat zij de nederzetting zullen mijden.

Vaak zijn de medicijnmannen, in het bijzonder door zendelingen, welbewuste bedriegers genoemd, die van de lichtgeloovigheid van hun stamgenooten tot hun persoonlijk voordeel misbruik maken. Dr. Karsten deelt geenszins deze meening; hij acht het zeker, dat de medicijnmannen, b.v. van de Toba's en de Matako geenszins bedriegers zijn, maar hun kunst ter goeder trouw uitoefenen. $\mathrm{Zij}$ deelen, zegt $\mathrm{Dr}$. K., vast het geloof van de geheele bevolking ten aanzien van den aard van de ziekte en hare genezing, en zijn in den grond niet meer „bedriegers” dan een geneeskundige in een beschaafde gemeenschap. In het voorwerp, dat zij als ziekte-oorzaak uit het lichaam van den zieke halen, achten zij den boozen geest op dat oogenblik belichaamd.

De manipulaties van den medicijnman hebben weinig van wat wij een natuurlijke geneeswijze noemen. De massage van de zieke plek en het zuigen kunnen verlichting geven. De Chaco Indianen 
gebruiken verschillende kruiden en grassen als geneesmiddel, en schrijven daar niet zelden geneeskracht aan toe. $\mathrm{Ze}$ worden veelal uitwendig toegepast en bestaan in het algemeen uit afkooksels, aftreksels van zekere bladen en wortels. Dr. K. gelooft niet, dat hunne geneesmiddelen veel uitwerken; de medicijnmannen schijnen ze bij hun behandeling slechts een ondergeschikte rol toe te kennen, maar de magische bezwering veel belangrijker te achten. Indien een patient door een medicijnman genezen wordt - wat niet zelden gebeurt - dan moet het verschijnsel in de eerste plaats worden toegeschreven aan zelfsuggestie van de zijde van den zieke, en het belang van dit soort van psychische behandeling moet bij primitieve volken niet worden onderschat.

De volledige titel van het besproken boek is: Societas Scientiarum Fennica, Commentationes Humanorum Litterarum IV. 1. The Indian Tribes of the Argentine and Bolivian Chaco, Ethnological Studies by Rafael Karsten, Ph. D., Professor of Moral Philosophy at the University of Helsingfors, Author of „The Civilization of the South American Indian”, etc. Read Januari 18th 1932, Helsingfors 1932. In deel 30, aflevering 2, 1933 van het „Journal de la Société des Américanistes de Paris" is een artikel verschenen van Elisabeth Dijour, „Les cérémonies d'expulsion des maladies chez les Matako" met vier groote afbeeldingen, die o.m. weergeven, dat een aantal dorpsbewoners, uithoofde van den ernst van het geval, gezamenlijk en op een rij loopende, de lastige booze geesten weder naar hunne bosschen terugjagen.

De heer Dr. A. Mètraux, hoogleeraar aan de Universiteit te Tucumán in Argentinië, die aldaar de „Revista del Instituto de Etnología" redigeert, heeft in den laatsten tijd reizen in het Chaco-gebied ondernomen. Ik vermoed, dat hij de door hem bij Chaco-Indianen gedane waarnemingen zal beschrijven in zijn „Revista”, dan wel in het genoemde Journal des Américanistes de Paris. Voor het onderwerp schijnt mij nog van belang het tijdschrift „Imago”, Zeitschrift für Anwendung der Psychoanalyse auf die Natur- und Geisteswissenschaften, uitgegeven door Sigm. Freud, XVIII Band, 1932, International Psychoanalytischer Verlag, Wien, waarin een artikel: „Instinktive Psychoanalyse unter den Navaho-Indianern" door Dr. O. Pfister, Berkeley (Californië) en Zürich.

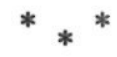


Over het onderwerp hield ik in 1934 te Leiden een voordracht in de voorjaarsvergadering van het Genootschap voor de Geschiedenis der Genees-, Natuur- en Wiskunde en het was daar, dat bij de discussie de bekende schrijver en geleerde Dr. M. A. van Andel (Gorinchem) een uiteenzetting gaf van de wijze, waarop zijns inziens de gedachtengang van den Indiaan over gewone en magische geneeswijzen was ontstaan. Dr. M. A. van Andel acht geen groot onderscheid aanwezig tusschen het gebruik van gewone geneesmiddelen en de toepassing van magische geneeswijzen. Hij meent, dat gebruik en toepassing als bedoeld in elkander overgaan. Zijns inziens ontwikkelen zich het bezigen van een geneesmiddel en het houden van een bezwering aldus, dat de Indiaan, de primitieve mensch, eerst, op welke wijze dan ook, bepaalde stoffen vindt, die tegen ziekte baat geven en hem heil brengen. Na die ervaring komt bij hem de gedachte op aan sommige hem nu bekend geworden middelen een magische werking toe te schrijven. Doordat hij aan het middel zelf of aan de toediening ervan bovennatuurlijke kracht toekent, ontstaat de magische geneeswijze.

Ik meen, dat Dr. Karsten's bevindingen met de overigens zoo duidelijke en logisch klinkende uitspraak van Dr. V. A. niet overeenkomen en dat de voorzichtigheid dus eischt een eindoordeel in deze zaak - eigenlijk een geweldig probleem, want het gaat om niet meer of minder dan het navorschen van den gedachtengang van de primitieve volken van den geheelen aardbol - op te schorten tot meer bewijsmateriaal ter beschikking ligt.

Thans overgaande tot mededeelingen, over ziekte-opvattingen en geneeswijzen bij Surinaamsche Indianen, wend ik mij tot den betrouwbaren en ik zou haast zeggen nuchteren A. Kappler, in zijn in 1887 te Stuttgart uitgegeven werk: Surinam, sein Land, seine Natur, Bevölkerung und seine Kultur-Verhältnisse mit Bezug auf Kolonisation. Deze vestigde zich in 1846 aan de Marowijne en vertrok van daar 33 jaar later; hij vermeldt op dezelfde bladzijde (236) dat hij in 1839 op de savanna-dorpen van de Boven-Maratakka eenige Arowakken-vrouwen ontmoette, waarvan hij den leeftijd op 100 jaar schatte. Hoofdzakelijk betreffen zijne opmerkingen de Caraïben, „unter dem ich viele Jahre lebte”, zoo zegt hij op blz. 212.

Over de ziekte van de Indianen sprekende verhaalt $\mathrm{K}$. eerst, dat zij zelden ziek zijn, maar het meest lijden aan mazelen en buikloop („Ruhren”), die dan, omdat zij zich niet aan een behoorlijke kuur onderwerpen, dikwijls doodelijk eindigen. Zelden, 
zoo vervolgt hij, vindt men ziekelijke personen; jicht en rheumatiek is bij den Indiaan onbekend, evenzoo de lepra. De Indiaan behoudt tot in zijn hoogsten ouderdom zijn volle zwarte haardos. Een groote physieke teruggang vond plaats door het misbruik van den op de fransche strafetablissementen verkrijgbaar gestelde sterken drank. Terwijl de neger in Europeesche artsen en medicijnen groot vertrouwen stelt, stelt de Indiaan zich slechts zelden onder behandeling van een beschaafd geneesheer, maar hij gebruikt hem bekende kruiden en vertrouwt zich bij ernstige ziekte slechts toe aan de bezweringen van den medicijnman. De patient moet in een hutje in zijn hangmat ineengedrongen liggen boven een vuurtje, terwijl de medicijnman in een ander hutje, onder voortdurend schudden van een ratel, met den (boozen) geest, die de ziekte veroorzaakt heeft, spreekt. Van tijd tot tijd komt de „piaiman” in het hutje van den zieke en blaast tabaksrook op de zieke plek. Deze rook en het steeds brandende vuurtje geven zulk een walm en hitte, dat ook zonder inwendige middelen, die „ebenfalls”, dus mede, gebruikt worden, een krisis ontstaat waarvan, zegt K. met eenige humor, der Patient genest oder stirbt. De bezweringen duren soms dagen en nachten. Als inwendige middelen noemt $\mathrm{K}$. afkooksels van wortels en kruiden, die in de europeesche heelkunde niet bekend zijn. In 1840 ondervond $\mathrm{K}$. de goede uitwerking van een aromatische bast. Als hoofdmiddel in zeer moeilijke gevallen zou het sap van den Dakini-boom worden aangewend, vermoedelijk een Sapotacee of Euphorbiacee.

Ik meen te kunnen vaststellen, dat zoowel bij de Chaco als bij de Indianen die Kappler in Suriname waarnam, bezweringen bij ziekte de belangrijkste geneeswijze uitmaken. De reden waarom beide categorieën in bezweringen heil zien, n.l. omdat daardoor de ziekte- veroorzakende geesten worden verdreven is dezelfde. $\mathrm{K}$. heeft echter aan de kracht uitgaande van de suggestie van den piaiman en aan de zelf-suggestie van den patient geen aandacht geschonken. Wellicht onbewust passen beide Indianen-groepen de zweetkuur toe met groote energie. Dat de Chaco-Indianen zich bewust zijn van een zekere immuniteit bij ieder mensch (zij het op onwetenschappelijke en geen steek houdende gronden) is zeker merkwaardig. 